\title{
Predicting Future Vegetated Landscapes Under Climate Change: Application of the Environmental Stratification Methodology to Protected Areas in the Lower Mekong Basin
}

\author{
John M. Johnston, Robert J. Zomer, and Ming-cheng Wang
}

\begin{abstract}
There are 176 protected areas within the Lower Mekong Basin (LMB), comprising $183,000 \mathrm{~km}^{2}$, almost $30 \%$ of the LMB. Climate change poses challenges to their management, because changes in the timing and amount of rainfall and maximum temperature from current (baseline) conditions alter vegetation growth and composition. The prediction of future climate, i.e., the pattern of temperature and rainfall expected 30-60 years from present, is accomplished using Earth System Models (ESMs). However, future ecosystem structure, including dominant vegetation, is less well studied. A successful approach is Environmental Stratification (EnS), involving statistical analysis of climate variables to identify relatively homogeneous spatial climate patterns (zones and strata) that are robust predictors of vegetation associations. Our objective was to predict changes in the spatial distribution of bioclimatic conditions across the LMB by the year 2030 and 2060, based on downscaled ( $1 \mathrm{~km}^{2}$ resolution) ESM projections. Five major bioclimatic zones and twenty-five bioclimatic strata were identified using EnS, ranging from extremely hot and xeric at the lower elevations, to warm temperate and mesic at higher elevations. The largest expanse of area is extremely hot and moist (50\% of total area), followed by extremely hot and xeric (24\%), and extremely hot and mesic $(18 \%)$, with mean annual temperature for the various zones ranging from 18.1 to $27.2^{\circ} \mathrm{C}$. More than $9 \%$ to $29 \%$ of all protected areas are projected to shift to a different bioclimatic zone by 2030, and from $7 \%$ to over $77 \%$ by 2060 .
\end{abstract}

\footnotetext{
J. M. Johnston ( $\square)$

US EPA Office Research and Development, Center for Environmental Measurement and Modeling, Athens, GA, USA

e-mail: Johnston.JohnM@epa.gov

R. J. Zomer · M.-c. Wang

World Agroforestry Center, Kunming, China

(C) The Author(s) 2020

T. G. O'Higgins et al. (eds.), Ecosystem-Based Management, Ecosystem Services

and Aquatic Biodiversity, https://doi.org/10.1007/978-3-030-45843-0_28
} 


\section{Lessons Learned}

- Up to $29 \%$ of protected areas will shift to a new bioclimatic zone by 2030 , necessitating adaptive management to adjust the current boundaries and their level of protected status.

- Ecosystem-based adaptation (EbA), a type of ecosystem-based management (EBM), provides a holistic approach to habitat and species protection under climate change.

- Coordinated management efforts across national boundaries will be important in the future of protected areas in the Lower Mekong Basin (LMB).

- Both environmental stratification (EnS) and the analysis of projected change in spatial distribution of bioclimatic conditions provide reliable information for climate change adaptation planning.

\section{Needs to Advance EBM}

- Conservation research and monitoring efforts in the LMB have focused more on freshwater ecosystems and species, and a greater emphasis is needed in the future on terrestrial ecosystems and vegetation assemblages as provided by EnS.

- EBM of terrestrial ecosystems, including protected areas, must account for human uses and co-existence, possibly through emphasis on non-timber forest products for food and livelihoods, permitting sustainable harvest of renewable resources by local populations.

- The interaction of aquatic and terrestrial systems in the LMB is a needed research area to achieve greater sustainability of the food-energy-water nexus.

- EbA strategies are needed in agricultural areas of the LMB, especially the Khorat plateau, where temperatures are expected to increase and rainfall decrease, leading to crop stress and failures, increasing food insecurity and further stressing protected areas.

\section{Introduction}

\subsection{Lower Mekong River Basin Context: Ecosystem, People and Challenges}

The Mekong River Basin beginning in Lao People's Democratic Republic (PDR) is referred to as the Lower Mekong Basin (LMB), and it supports over 60 million people (MRC 2011c). The LMB includes portions of the riparian countries of Lao PDR, Vietnam, Cambodia and Thailand. It is estimated that over $60 \%$ of the LMB population is connected to the Mekong River for its food and livelihood (Fig. 1). Lao PDR and Cambodia plan to graduate from least developed country status by 2020 , with Vietnam achieving middle-income status by 2030. Aquaculture is forecast to double to 4 million metric tons in 20 years, with dry season irrigation expansion planned to increase by $50 \%$ to 1.8 million ha, including mainstream water transfers planned by Thailand to alleviate drought conditions in the Northeast (MRC 2011a). 


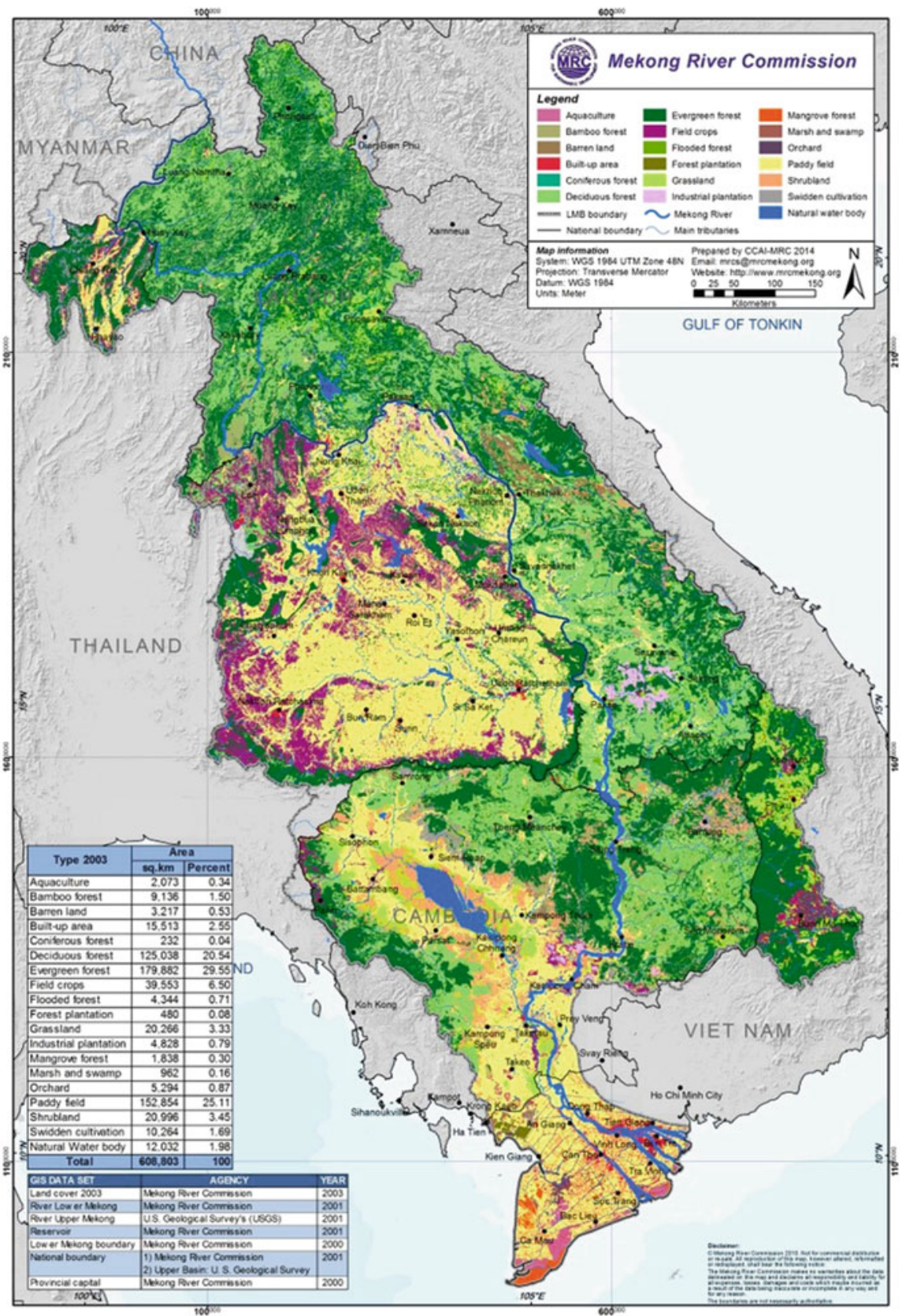

Fig. 1 Lower Mekong Basin study area. Land cover types are provided basinwide for all watersheds contributing to the Mekong River 
The food, water, and energy needs of the population are therefore expected to increase pressure on LMB ecosystems, with climate change an additional longterm driver to be considered. The Mekong River Commission (MRC) was created in 1995 by the riparian governments of the LMB to promote sustainable development for the greater good of all countries (MRC 2011c).

Although the overall amount of water is not considered limiting in the LMB, the Southwest Monsoon results in strong seasonality of rainfall, with very little precipitation occurring in the dry season from November through May. Dry season food cultivation is dependent on irrigation from surface waters of the river and adjacent ecosystems. Because of their interdependence, water, energy, and food must be managed concomitantly, with careful consideration of tradeoffs that directly and indirectly affect the nexus (Linke 2014; Rasul 2014). Downstream ecosystems and national and local community dependence on flows from the northern basin are transboundary issues that require integrated planning and coordination. As a type of Ecosystem-Based Management (EBM), attention is being given to ecosystem-based adaptation (EbA) strategies for managing climate change impacts (Munang et al. 2013; Sierra-Correa and Cantera Kintz 2015; Vignola et al. 2013; Wamsler et al. 2014). An EbA strategy balances infrastructure development with investments in natural capital for more resilient and sustainable solutions. Protection of LMB watersheds contributing flow and material input to the Mekong is a primary EbA strategy in consideration (ISPONRE 2013; MONRE 2013).

These promising examples of national-level initiative within the LMB for EbA to climate change impacts were developed for Vietnam and Lao PDR. Each provides a national level operational framework for a participatory process of mainstreaming ecosystem services concepts and practices, outlining a fairly detailed process with example tools and methods to facilitate replication of the framework. A guide for decision makers is also recommended as a companion document with more detailed descriptions and examples of the concepts (Ranganathan et al. 2008). An important and necessary complement to the national level is a basin-wide strategy for transboundary adaptation planning in the LMB. Ecosystem services of water, nutrient, and sediment provisioning provided by upstream forest and wetland ecosystems are critical to maintaining delta fisheries and agricultural productivity and protection from saltwater intrusion, because many of the impacts of climate change cannot be managed effectively at the national level. Only when the suite of transboundary adaptation strategies are fully addressed will the MRC vision of "an economically prosperous, socially just, and environmentally sound Mekong River Basin” be realized (MRC 2010).

Within the MRC, the Climate Change and Adaptation Initiative (CCAI) has the mission of climate change impact assessment and adaptation planning and implementation within the LMB. CCAI has the objective of guiding climate change adaptation planning and implementation through improved strategies and plans at various levels and in priority locations throughout the LMB, which includes a mix of scoping, synthesis, outreach, and capacity building (MRC 2011b). A critical role of the MRC CCAI is to provide a consistent, basin-wide approach for evaluating transboundary climate change adaptation. The CCAI is dedicated to developing 
basin-wide datasets and assessment methods that can be used at multiple spatial scales (e.g., nationally and locally) whether data rich or data limited. This is an essential role of CCAI: no other group is committed to providing the basin-wide context for national studies and the ability to compare results consistently across the LMB. Outputs include basin-wide datasets, verified ecosystem modeling methods and knowledgebase for reuse by member countries, and the identification of data gaps and priorities for reducing uncertainty. The CCAI is responsible for providing data and modeling methods that are well documented (e.g., user's guides, peerreviewed literature), freely available, and could be used at multiple spatial scales, from basin-wide assessments to province-level if needed within member countries. Forecasting the impacts of climate change on ecosystems and biodiversity was a focus of the CCAI (Trisurat et al. 2018), with multiple ecosystem service forecasting models in consideration for potential use in the LMB.

\subsection{Landcover Change and Ecosystem Models for Scenario Analysis}

Landcover data provide an efficient means of working with large geographic regions, and a number of models have been developed to utilize these data to characterize ecosystem services (Bagstad et al. 2013a, 2013b; Feng et al. 2011; Jackson et al. 2013; Vigerstol and Aukema 2011). The majority of these ecosystem services models utilize landcover data as input to quantify services and their value using biophysical models with a statistical or empirical formulation, a necessary strategy when working in data limited areas (Bagstad et al. 2013a; Daily et al. 2009). Attributes that differentiate the approaches, making some models more suitable than others, include availability, maturity, flexibility, and ease of use. The InVEST model developed by The Natural Capital Project is freely available, well documented, includes economic valuation methods, and has been applied around the world at multiple spatial scales to evaluate the impacts of land use and climate change. Examples include the impact of land use change on water yield, carbon storage, nutrient retention, sediment retention and biodiversity provisioning (Leh et al. 2013), the impact of hurricane and typhoon disturbance on water yield, water purification, soil conservation, carbon storage and biodiversity (Chiang et al. 2014), timber production and carbon sequestration losses due to hurricane damage (Delphin et al. 2013), sediment retention and water yield under land use and climate change (Su and Fu 2013), the impact of climate change on water yield for a low flow regime in a river basin (Marquès et al. 2013), and to assess the combined effects of land use and climate change scenarios on water yield, nutrient and sediment retention in 2050 (Hoyer and Chang 2014).

The InVEST model has also been used to evaluate payment for ecosystem services schemes and the value of hydropower energy production (Fu et al. 2014) and the economic value of wetland ecoservices water purification and carbon 
sequestration under three land use change scenarios (Harmáčková and Vačkáŕ 2015). Water-related ecosystem services have received the most attention compared to other services, and Vigerstol and Aukema contrasted the InVEST and ARIES models for freshwater services provisioning with the watershed hydrologic models SWAT and VIC (Vigerstol and Aukema 2011). Sánchez-Canales et al. performed a sensitivity analysis of the InVEST water yield model and found it most sensitive to potential evapotranspiration and rainfall (Sánchez-Canales et al. 2012). Bai et al. used InVEST to evaluate the correlation and spatial overlap of sediment and nutrient retention, water yield and biodiversity services for possible management and restoration of regional hotspots (Bai et al. 2011). The InVEST model had been applied successfully within the LMB to address climate change impacts (ISPONRE 2013; MONRE 2013; Rosenthal et al. 2013). However, none of these models or approaches provides a forecast of future vegetation composition. Often, the most recent landcover data are used, held constant over the analysis period, or assumed to have a future composition as in scenario analysis. In this chapter, we explore Environmental Stratification (EnS) to develop bioclimatic strata and major bioclimatic zones for analyzing potential changes in LMB protected areas under different climate scenarios. EnS was selected by the CCAI to forecast future bioclimatic zones and the related vegetation structure in 2030 and 2060 and used to support the protected area analysis basinwide.

\subsection{Environmental Stratification}

Environmental Stratification (EnS) is a statistical technique for analyzing climate variables to identify relatively homogeneous spatial climate patterns (i.e., strata) that are in turn strongly associated with plant species and can serve as robust predictors of vegetation associations. Metzger et al. proposed using EnS to create a consistent, national to global biodiversity observation network (Metzger et al. 2013a, 2013b), based on a methodology involving maximum likelihood analysis and clustering (Zomer et al. 2014, 2015). Metzger et al.'s global bioclimatic map has been used to develop regional maps of climate associations and also as a reference for comparison with regional data (Zomer et al. 2014). The MRC and CCAI maintains basinwide climate and landcover data for the LMB that includes dominant vegetation types; these include, for example, coniferous, deciduous, and evergreen forests that are the necessary inputs for the EnS methodology (Fig. 1).

\subsection{Biodiversity and Protected Areas in the LMB}

Effective management of LMB ecosystems and their services requires a baseline assessment of status and ongoing monitoring and evaluation to assess the outcomes of decisions. This provides the necessary information for EbA—a key EBM strategy 
for navigating an uncertain future. As an example, forest ecosystems provide services related to wild foods and non-timber forest products (NTFPs). Households with access to productive forestlands have adaptation strategies not available to the population living in urban areas when food becomes scarce or expensive. Livelihoods are also supported from NTFP harvesting that brings income. The overall climate change adaptation strategy is one of decentralization to provide greater access and opportunity to the population. This is particularly important to communities in rural areas that have less resources and may have fewer options compared to those living in cities. The implication is that food security should consider the contribution of forest ecosystems to unconventional food supplies and subsistence economic opportunities. This is reinforced by a recent survey of biodiversity in Lao PDR: "The plants and animals harvested in the Mekong and its surrounding habitats provide an important source of food and income for the people who live along its banks" (IUCN 2013). Others have gone further to state that shifting agricultural practices in forest ecosystems are inherently more sustainable because they are less intensive and co-exist with forest ecosystems (Yokoyama et al. 2006). Numerous international experts recommend that "ecosystem-based approaches can contribute to climate change mitigation and adaptation and to sustainable development more broadly. Spatial planning for ecosystem services at international, national and local levels will be an important component of ecosystem-based approaches" (Leadley et al. 2010). The initial focus was on evaluating landscape change basin-wide and the use of these data to characterize selected ecosystem services for water provisioning and nutrient and sediment retention (Trisurat et al. 2018). Although protected areas and biodiversity had been evaluated at the provincial level, e.g., Nan Province, Thailand, it did not include climate impacts on bioclimatic zones that support terrestrial ecosystems (Trisurat et al. 2019). Changes in rainfall and temperature will influence vegetation patterns, potentially shifting species ranges to higher elevations and favoring new dominant and co-dominant plants compared with current communities (Zhang et al. 2014). Protected areas that are unchanging will likely fail to provide the range of habitats and corridors necessary for species to adapt to climate change (Monzón et al. 2011).

\section{Study Area and Methods}

The Mekong River in Southeast Asia drains an area of $795,000 \mathrm{~km}^{2}$ that is referred to as the Lower Mekong Basin (LMB, Fig. 1). Annual mean precipitation ranges from approximately $1000 \mathrm{~mm}$ in northeast Thailand to over 3,500 $\mathrm{mm}$ in northern Lao PDR (Trisurat et al. 2018). This vast aquatic ecosystem flows over $4,800 \mathrm{~km}$ from its source in the Tibetan Plateau to the South China Sea below Ho Chi Minh. Of the approximately $475 \mathrm{~km}^{3}$ annual average discharge, $12 \%$ or 60 billion $\mathrm{m}^{3}$ are withdrawn for agricultural, industrial and other consumptive use. Hydropower energy potential of the LMB is estimated at 30,000 MW with only $10 \%$ developed; however, 26 hydropower projects are underway, with 12 mainstream and 30 tributary 
Table 1 Protected areas in the Lower Mekong Basin

\begin{tabular}{|c|c|c|c|c|}
\hline \multicolumn{5}{|c|}{ Lower Mekong Basin } \\
\hline \multirow[b]{2}{*}{ IUCN category } & \multicolumn{2}{|c|}{ Protected area } & \multicolumn{2}{|l|}{ Area } \\
\hline & No. of PAs & $\%$ of PA & $\mathrm{km}^{2}$ & $\%$ \\
\hline Ia & 20 & 11.4 & 10,054 & 5.5 \\
\hline II & 56 & 31.8 & 35,683 & 19.5 \\
\hline III & 1 & 0.6 & 130 & 0.1 \\
\hline IV & 27 & 15.3 & 36,524 & 20.0 \\
\hline $\mathrm{V}$ & 8 & 4.5 & 6,431 & 3.5 \\
\hline VI & 22 & 12.5 & 37,267 & 20.4 \\
\hline Not Applicable & 10 & 5.7 & 39,069 & 21.3 \\
\hline Not Reported & 33 & 18.8 & 17,914 & 9.8 \\
\hline Grand Total & 176 & 100.0 & 183,071 & 100.0 \\
\hline
\end{tabular}

IUCN categories provided by number (No.) of protected areas (PA), \% of total PA, area in $\mathrm{km}^{2}$ and $\%$ of total area for each category

Source: UNEP-WCMC (2019)

dams planned over the next 20 years (MRC 2011a). Ecosystem services provide food, water, and energy security to the extent they can be maintained in the face of a growing population and increasing demand for food and energy (MEA 2005). This includes services for habitat for protected species, with landcover and protected area data provided by the MRC (MRC 2011c). According to the World Database on Protected Areas (UNEP-WCMC 2019), there are 176 protected areas within the Lower Mekong Basin (LMB), comprising 183,000 $\mathrm{km}^{2}$, almost $30 \%$ of the total LMB (Table 1). Excluding IUCN (International Union for Conservation of Nature) categories "Not Applicable" and "Not Reported", protected areas still account for over $20 \%$ of the LMB.

Baseline climate was derived from data averaged from 1980 through 2010, while 2030 represented a 30-year average of the period 2015 to 2045, and 2060 represented the period 2045 to 2075 for terrestrial ecosystems using ESM ensemble climate forecasts from the SimCLIM dataset (Trisurat et al. 2018). The EnS methodology used the SimCLIM set of selected ESM and emissions scenario combinations, which included a multi-model ensemble $(n=13)$ of Coupled Model Intercomparison Project 5 (CMIP5, https://esgf-node.llnl.gov/projects/cmip5/) ESMs applied across three representative concentration pathways (RCP 2.6, 4.5, $8.5)$, to assess climate change impacts on vegetation growing conditions. Consistent with the Fourth National Climate Assessment (USGCRP 2018), the RCPs span a range of lower to higher greenhouse gas (GHG) concentration, corresponding to increased radiative forcing of $2.6,4.5$, and 8.5 watts per square meter $\left(\mathrm{W} / \mathrm{m}^{2}\right)$. In other words, scenario RCP8.5 involves annual GHG emissions increasing throughout the twenty first century, leveling off by 2100, while lesser RCPs represent decreased GHG emissions (USGCRP 2018). Most global climate modeling experts agree that the biosphere is already experiencing a trajectory consistent with RCP8.5, unless substantial GHG emission mitigation steps are taken immediately, worldwide. Climate-envelope models identify constraints on species geographic ranges 
related to aspects of temperature, precipitation, relative humidity, including the minimum and maximum values (Lassiter et al. 2000). Bioclimatic envelopes characterize to the extent feasible the complete set of conditions conducive to ecosystems, species, and biological interactions, and are therefore used to gauge the impacts of climate change across the LMB protected areas.

\section{Results}

Five bioclimatic zones comprised of 25 bioclimatic strata were found within the LMB (Fig. 2), with zones ranging from extremely hot and xeric at the lower elevations to warm temperate and mesic at higher elevations. Mean annual temperatures are typically inversely correlated with average elevation. Additionally, 92.5\% of the bioclimatic zones in the LMB are classified as extremely hot at baseline, and this percentage is expected to increase in 2030 under RCP8.5 (Table 2). Of particular note in 2030 is the reduction of the extent of the warm temperate and mesic zone from $1.5 \%$ to $0.2 \%$. This represents a substantial, near-term loss of an already rare bioclimatic zone. There is also an increase in extremely hot and xeric (dry) from $11.4 \%$ to $17.1 \%$ (Table 2). By the year 2060 the zones appear to be limited to two primary types, extremely hot and mesic and extremely hot and moist, comprising 93.2\% of the total area. Baseline LMB climate generally provides moist to mesic conditions conducive to forested ecosystems and rainfed agriculture; however, the warm temperate and mesic zone within protected areas diminishes under all scenarios and nearly disappears under RCP 8.5 by 2060 . Bioclimatic zones for baseline and future climates in 2030 and 2060 across all emissions scenarios are illustrated (Fig. 3) and summarized for year 2060 across all emissions scenarios and compared to baseline and the entire LMB (Fig. 4).

The mean elevation of the bioclimatic zones within protected areas shifted upwards within mountainous terrain and across large plains or plateaus with elevation gradients under higher emission scenarios (Table 3). The extremely hot and mesic zone decreased in elevation; however, this is an artifact of the dramatic increase in extent of this zone across the LMB. The lower elevation, extremely hot and xeric zone shifted only marginally upslope in the highest emissions scenario by 2060, reflecting the small extent of this bioclimatic zone.

To emphasize the magnitude of bioclimatic change accompanying climate change, the percentage of the total area of each protected area that shifts to a different bioclimatic zone is shown (Fig. 5). Percent shifts in bioclimatic zone and strata are also summarized for the LMB and across all protected areas for both 2030 and 2060 and across all emissions scenarios (Table 4). Greater than $11 \%$ to almost $38 \%$ of the LMB is projected to shift to a different bioclimatic zone by 2030 , and $9 \%$ to almost $88 \%$ will shift to a new bioclimatic zone by 2060 under RCP 8.5 (Table 4). Basinwide results were slightly greater than compared to protected areas, with $9 \%$ to $29 \%$ projected to shift to a different bioclimatic zone by 2030 and from $7 \%$ to more than $77 \%$ by 2060 . 


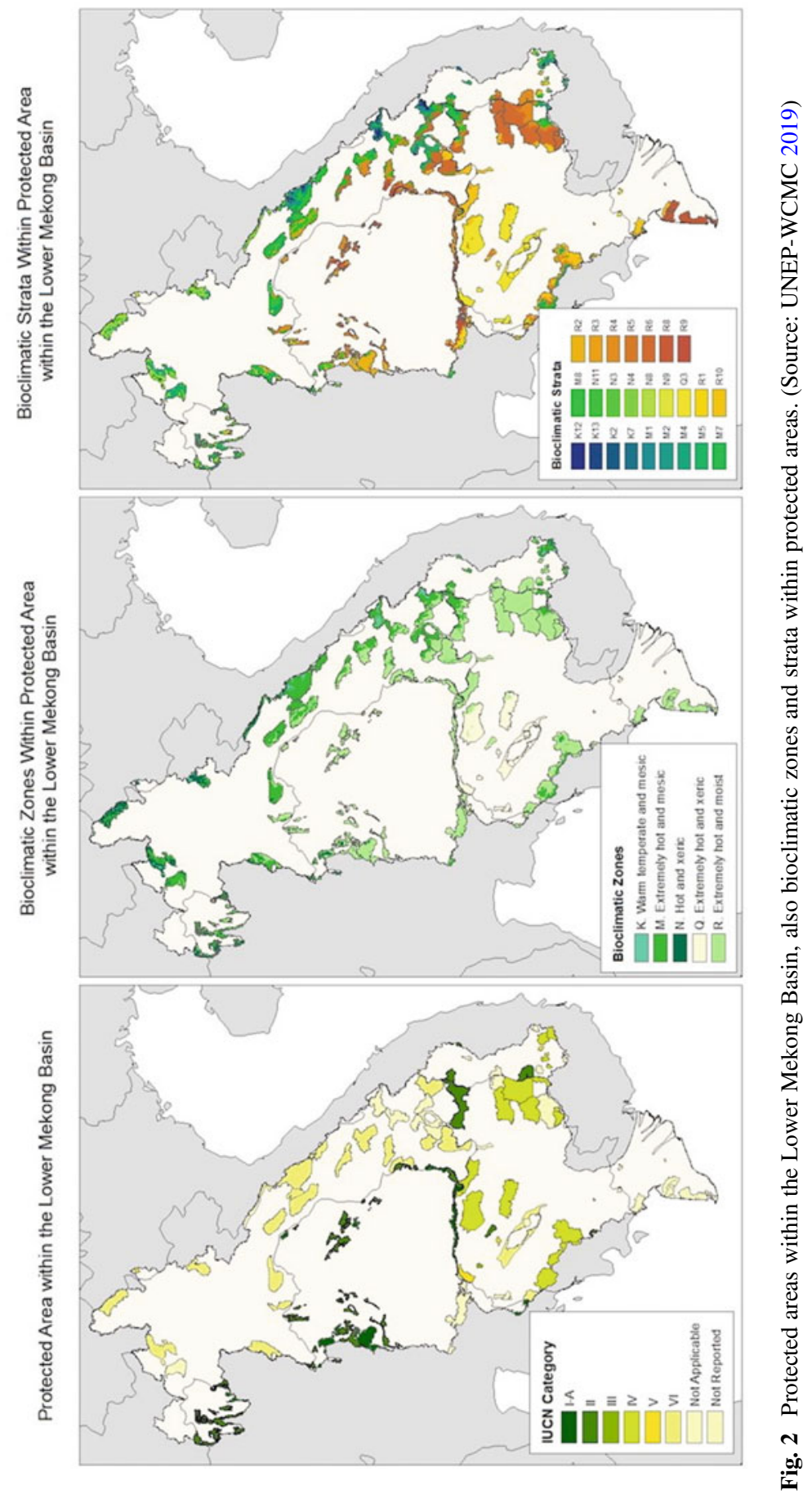




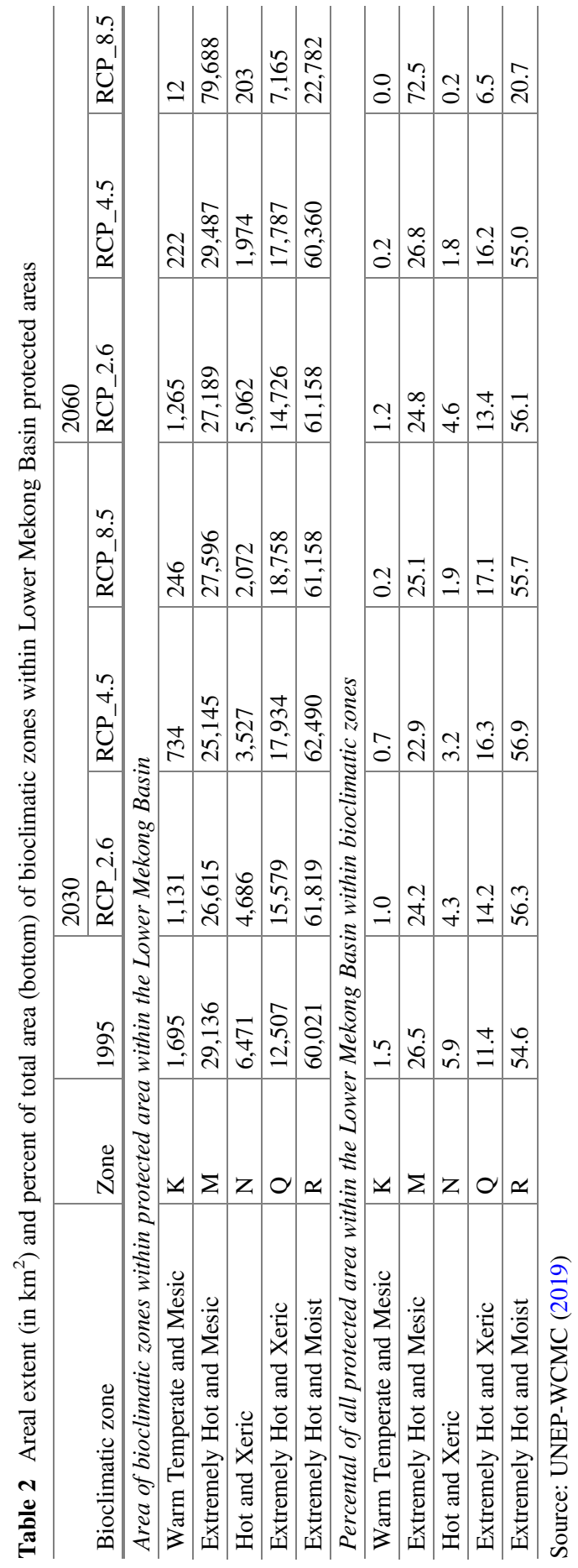


EnS Bioclimatic Zones within Protected Area Lower Mekong Basin - Ensemble ( $n=13)$

Year:1995

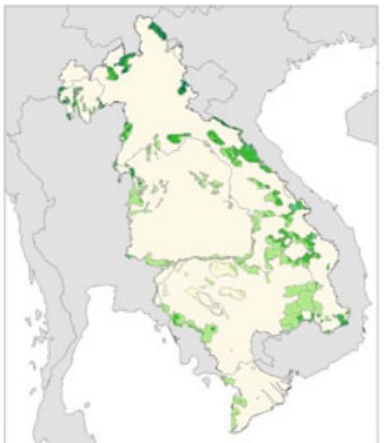

\section{Year: 2030}

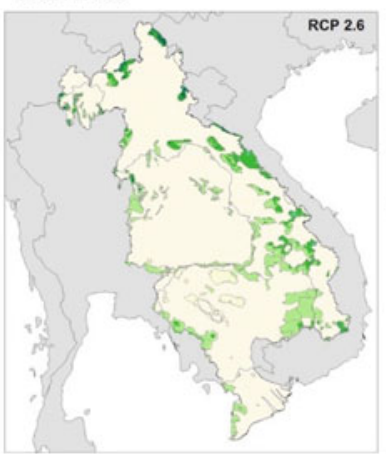

Year: 2060

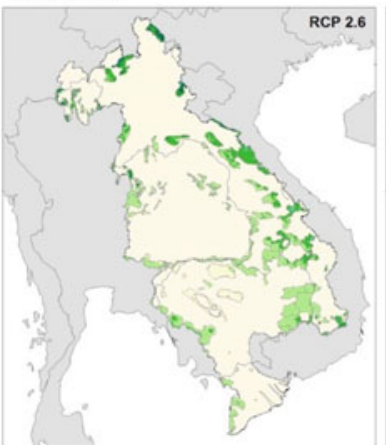

\section{Biocllimatic Zones}

K. Warm temperate and mesic

M. Extremely hot and mesic

N. Hot and dry

Q. Extremely hot and xeric

R. Extremely hot and moist
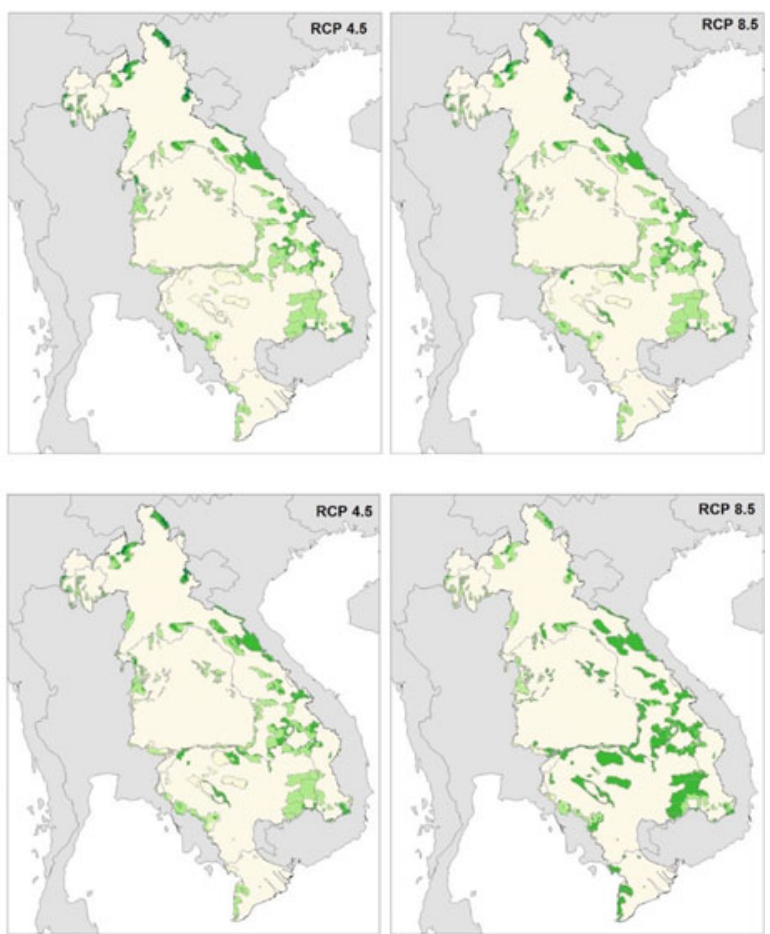

Fig. 3 Environmental Stratification (EnS) bioclimatic zones within protected areas in the Lower Mekong Basin, for baseline (1995), and 2030 and 2060 under emission scenarios RCP 2.6, 4.5, and 8.5 
a.) Areal Exten to Bioclimatic Zones - 1995-2060 - Lower Mekong Basin

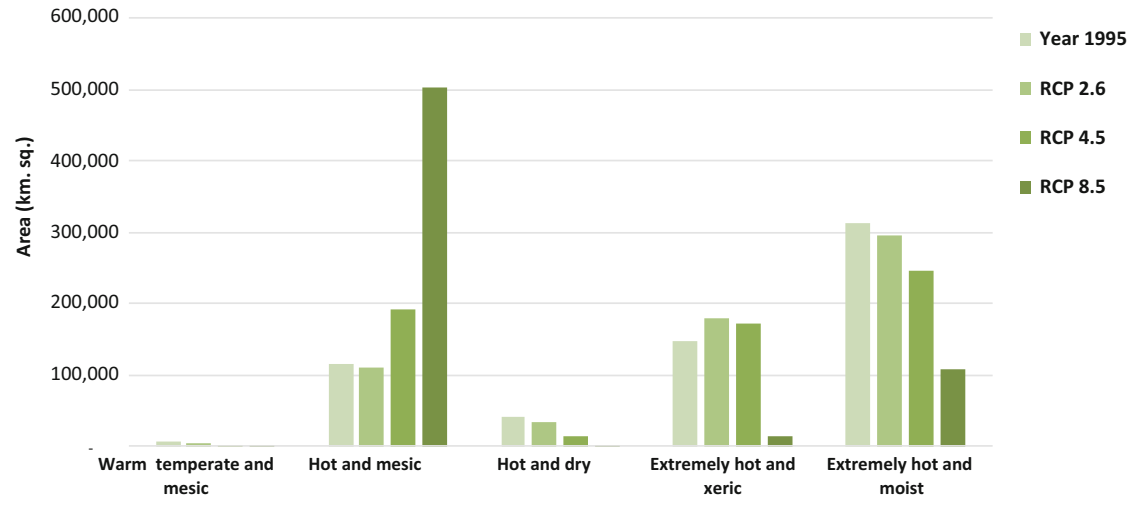

b.) Areal Extent of Bioclimatic Zones within Protected Area Network - 1995-2060 - Lower Mekong Basin 100,000

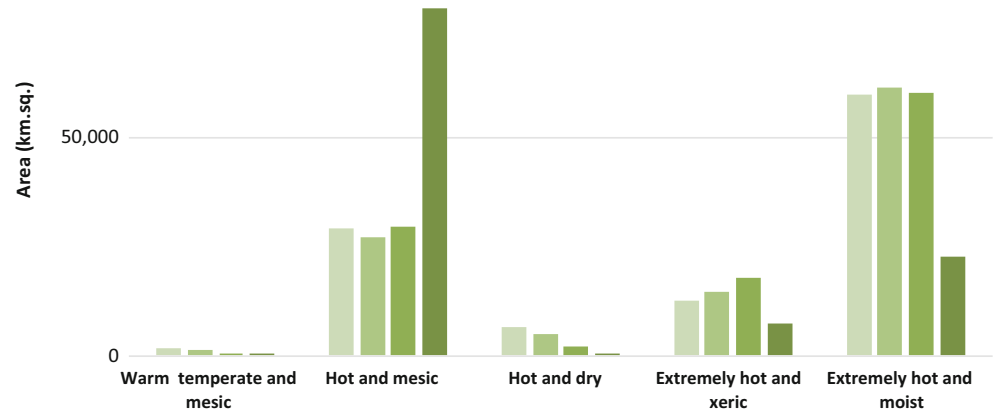

c.) Percent of Protected Area Network within each Bioclimatic Zone - 1995-2060 - Lower Mekong Basin 100

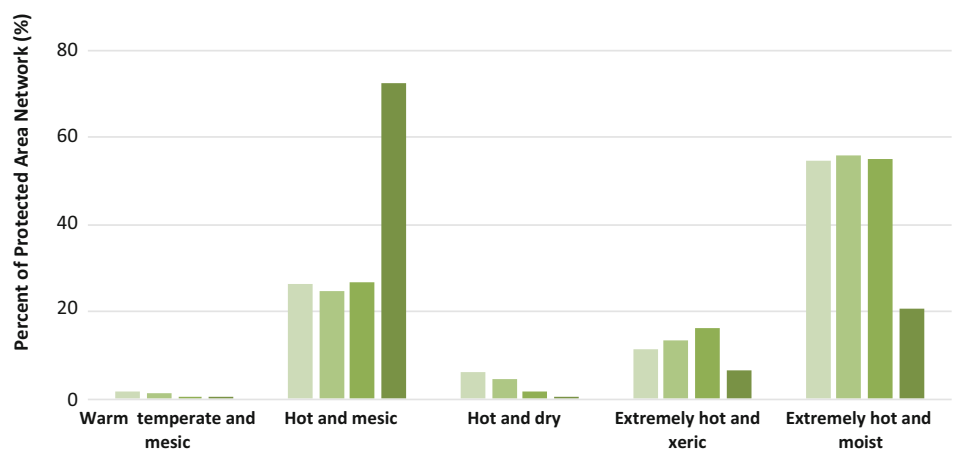

Fig. 4 The extent of bioclimatic zones in the Lower Mekong Basin (a) basinwide, (b) within protected areas, and (c) as percent of the total protected area in bioclimatic zone, from baseline (1995) to 2060 under three emission scenarios RCP 2.6, 4.5, and 8.5 
Table 3 Projected change in the mean elevation above sea level ( $\mathrm{m}$ asl) of bioclimatic zones in protected areas within the Lower Mekong Basin by 2030 and 2060, under three emission scenarios RCP 2.6, 4.5, and 8.5

\begin{tabular}{|c|c|c|c|c|c|c|c|c|}
\hline \multirow[b]{3}{*}{ Bioclimatic zone } & \multirow[b]{3}{*}{ Zone } & \multicolumn{4}{|c|}{ Elevation } & \multicolumn{3}{|c|}{ Elevation shift } \\
\hline & & 1995 & $\begin{array}{l}\text { RCP } \\
2.6\end{array}$ & $\begin{array}{l}\text { RCP } \\
4.5\end{array}$ & $\begin{array}{l}\text { RCP } \\
8.5\end{array}$ & $\begin{array}{l}\text { RCP } \\
2.6\end{array}$ & $\begin{array}{l}\mathrm{RCP} \\
4.5\end{array}$ & $\begin{array}{l}\mathrm{RCP} \\
8.5\end{array}$ \\
\hline & & \multicolumn{4}{|l|}{$\mathrm{m}$ asl } & \multicolumn{3}{|l|}{$\mathrm{m}$} \\
\hline
\end{tabular}

Projected change in mean elevation of bioclimatic zones and their upward shift by 2030-LMB

\begin{tabular}{l|l|r|r|r|r|l|l|l}
\hline $\begin{array}{l}\text { Warm temperate and } \\
\text { Mesic }\end{array}$ & $\mathrm{K}$ & 1,535 & 1,601 & 1,666 & 1,823 & 66 & 131 & 288 \\
\hline $\begin{array}{l}\text { Extremely hot and } \\
\text { Mesic }\end{array}$ & $\mathrm{M}$ & 721 & 783 & 824 & 564 & 62 & 103 & $(\mathbf{1 5 7})$ \\
\hline Hot and Xeric & $\mathrm{N}$ & 1,130 & 1,206 & 1,263 & 1,364 & 76 & 133 & 235 \\
\hline $\begin{array}{l}\text { Extremely Hot and } \\
\text { Xeric }\end{array}$ & $\mathrm{Q}$ & 96 & 106 & 112 & 129 & 10 & 16 & 32 \\
\hline $\begin{array}{l}\text { Extremely Hot and } \\
\text { Moist }\end{array}$ & $\mathrm{R}$ & 219 & 252 & 279 & 332 & 33 & 59 & 113 \\
\hline
\end{tabular}

Projected change in mean elevation of bioclimatic zones and their upward shift by 2060-LMB

\begin{tabular}{l|l|r|r|r|r|r|l|l}
\hline $\begin{array}{l}\text { Warm Temperate and } \\
\text { Mesic }\end{array}$ & $\mathrm{K}$ & 1,535 & 1,584 & 1,837 & 2,211 & 50 & 303 & 676 \\
\hline $\begin{array}{l}\text { Extremely Hot and } \\
\text { Mesic }\end{array}$ & $\mathrm{M}$ & 721 & 769 & 496 & 268 & 48 & $\mathbf{( 2 2 5 )}$ & $\mathbf{( 4 5 3 )}$ \\
\hline Hot and Xeric & $\mathrm{N}$ & 1,130 & 1,188 & 1,373 & 1,694 & 58 & 243 & 564 \\
\hline $\begin{array}{l}\text { Extremely Hot and } \\
\text { Xeric }\end{array}$ & $\mathrm{Q}$ & 96 & 104 & 134 & 504 & 8 & 38 & 408 \\
\hline $\begin{array}{l}\text { Extremely Hot and } \\
\text { Moist }\end{array}$ & $\mathrm{R}$ & 219 & 244 & 344 & 733 & 24 & 125 & 513 \\
\hline
\end{tabular}

Numbers in bold indicate a negative shift

\section{Discussion}

As indicated by the roughly one-third (year 2030, RCP8.5) and two-thirds (2060, $\mathrm{RCP} 8.5$ ) of protected areas shifting to a new bioclimatic zone from baseline, climate change will have a substantial impact on protected areas in the LMB. Bioclimatic zones correspond to major vegetation assemblages (i.e., dominant and co-dominants) and translate broadly to landcover types such as coniferous, deciduous and evergreen forest. Zonal transitions are more profound than strata regarding ecosystem change, because a shift to a different bioclimatic zone indicates novel bioclimatic conditions with direct consequences for the biota and ecosystem function of that protected area. Changes in bioclimatic strata correspond to the level of vegetation species and can be investigated further if foundation species are of interest. Understanding the nature and direction of these changes provides crucial information for adaptation planning and management. In the near term (year 2030, RCP8.5) protected areas in central and northern LMB require attention to adaptation planning (i.e., average zonal shifts of $60 \%$ or greater). By 2060, under emissions scenario RCP8.5, protected areas all across the LMB are at risk. Only a few protected 


\section{Percent Shift of EnS Bioclimatic Zones within Protected Area ( \%)} Lower Mekong Basin - Ensemble $(n=13)$

Year: 2030

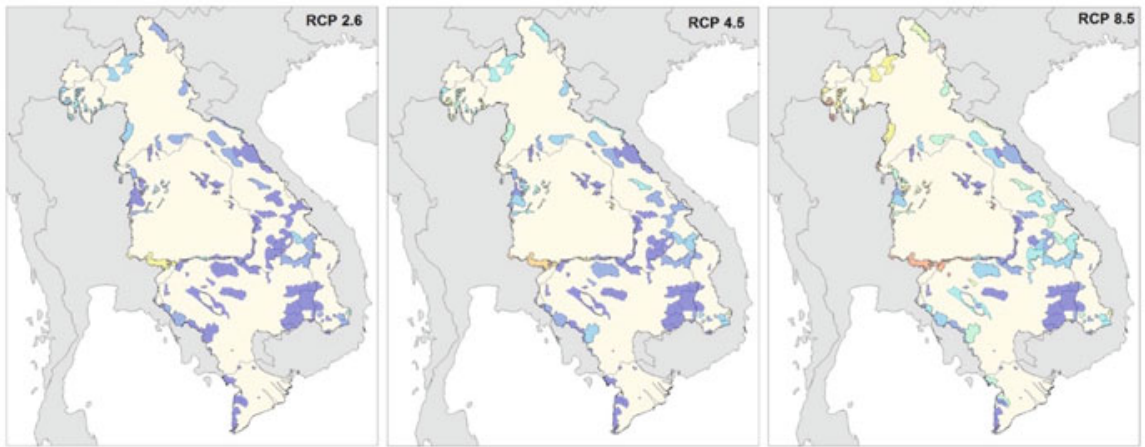

Year: 2060

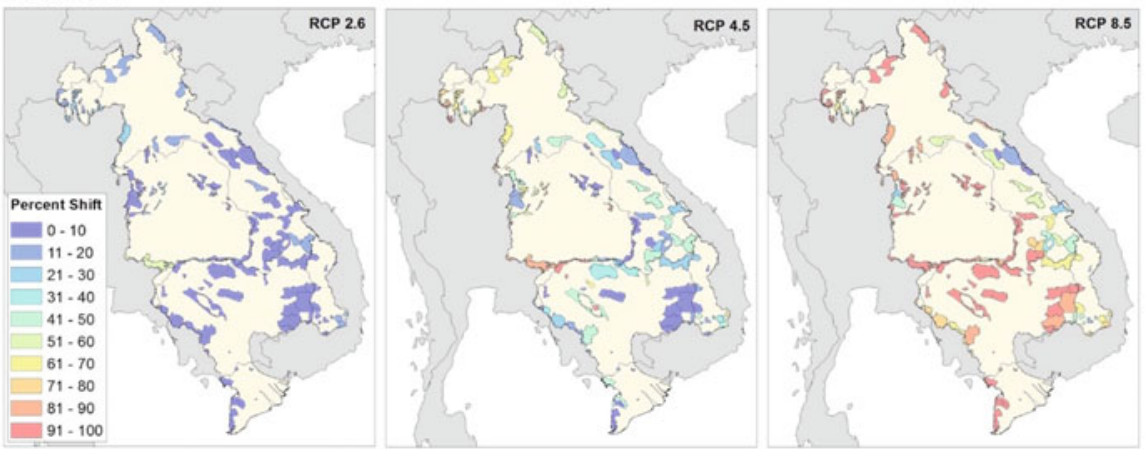

Fig. 5 Average percent of protected areas within the Lower Mekong Basin that shifted to a different bioclimatic zone from baseline (1995) as projected for 2030 and 2060 across three emission scenarios RCP 2.6, 4.5, 8.5

Table 4 Percent of total area for the Lower Mekong Basin (LMB) and protected areas that shifted to a different bioclimatic zone or strata by 2030 and 2060, under three emission scenarios RCP 2.6, 4.5 , and 8.5

\begin{tabular}{|c|c|c|c|c|c|c|}
\hline \multicolumn{7}{|c|}{ Percent of area shifting to a different bioclimatic zone or strata } \\
\hline & \multicolumn{3}{|l|}{2030} & \multicolumn{3}{|l|}{2060} \\
\hline & RCP 2.6 & RCP 4.5 & RCP 8.5 & RCP 2.6 & RCP 4.5 & RCP 8.5 \\
\hline \multicolumn{7}{|l|}{ Bioclimatic zones } \\
\hline LMB-all & 11.8 & 19.6 & 37.4 & 9.2 & 42.2 & 87.7 \\
\hline LMB-Protected area & 9.3 & 16 & 29.1 & 7.1 & 31.7 & 77.6 \\
\hline \multicolumn{7}{|l|}{ Bioclimatic strata } \\
\hline LMB-all & 24.6 & 38.2 & 57.8 & 19.4 & 62.5 & 94.8 \\
\hline LMB-Protected area & 32.1 & 50.8 & 68.2 & 24.9 & 70.4 & 90.2 \\
\hline
\end{tabular}


areas are expected to experience minimal zonal shifts (i.e., average shift of 0-20\%), and these areas are mainly located along the mountainous border of Lao PDR and Vietnam. Moreover, climate change is a landscape-level disturbance that is expected to substantially impact the effectiveness of the protected areas and conservation efforts across the LMB. Coordination will be needed across provincial and national borders to compensate for the projected bioclimatic shifts.

The need to synthesize existing data and knowledge of LMB ecosystems and their services is fundamental to EBM. A comprehensive, basin-wide characterization of the natural capital of the LMB is the foundation of an accurate accounting of the costs and benefits of sustainable development decisions to society: "To date there has been no comprehensive overview of the value of ecosystem benefits in the region, leading to a serious undervaluing by both politicians and even many local communities. A full review of Mekong ecosystem services is urgently overdue" (WWF 2013). Ideally, this should also include a comprehensive review of beneficiaries of final ecosystem goods and services (Ringold et al. 2010).

According to various international experts (Leadley et al. 2010), the greatest drivers of ecosystem and biodiversity change are "land use change, modification of river flow, freshwater pollution, and exploitation of marine resources" with "climate change and ocean acidification increasingly important drivers during the twenty first century." This suggests that the freshwater ecosystems, fisheries, and forests of the LMB are most threatened in the near term. Furthermore, "if greenhouse gas emissions continue along current trajectories, several Earth System models project that this will result in far greater climate-induced transformations of terrestrial biomes and marine biota than projected in earlier global biodiversity assessments." There is reason for optimism though, as the authors point out that "new socio-economic scenarios point to plausible development pathways of low greenhouse gas emissions and low land conversion that could lead to much lower biodiversity impacts." These scenarios of future development may be optimistic, but they are consistent with sustainable development goals and "require fundamental changes in development paradigms, but are coherent with known constraints on economics, resource use and human development goals" (Leadley et al. 2010).

There are challenges though to a complete characterization of LMB ecosystems. There is no single authoritative source, and there are gaps in the data which require further research for both freshwater and forest ecosystems, including habitat quality (WWF 2013). An exception is the ecological study of the Mekong upper floodplain and wetlands above Vientiane (IUCN 2013). This study is also exceptional for its companion socioeconomic study of community livelihoods along the river and surrounding forest that describe human uses of natural capital for both food and household income (Singer 2013). The Critical Ecosystem Partnership Fund provided a comprehensive review of hotspots of conservation potential in the larger IndoBurma region that includes the LMB (CEPF 2011). Their strategic review addressed not only biodiversity but also the important social, legal, and political dimensions that must be considered when allocating resources for conservation of natural capital. However, the scope of their review is broad and provides little information for ecoregion characterization. 
The World Wildlife Fund, with an ecosystem services emphasis, conducted a study of forest cover change in the Greater Mekong and compared their results to other data sources (WWF 2013). They provided maps contrasting two alternative scenarios that spanned a green energy, conservation-balanced future with businessas-usual exploitation of natural capital. They also addressed freshwater ecosystems, identifying 13 distinct but connected aquatic systems along the Mekong. The authors caution that information on ecosystem quality is particularly lacking. For example, remotely-sensed landcover data products typically do not discriminate between primary forest and disturbed, fragmented forest cover, although primary forest is known to be scarce in Lao PDR and Thailand (WWF 2013).

Overall, our understanding of social, economic and environmental system interactions and their dynamics is in its infancy, and experts argue in favor of a precautionary approach. The combined effects of time lags between drivers of ecosystem response and the measured indicators, thresholds of system change that result in nonlinear, accelerated response, and tipping points of irreversible ecosystem change, mean that "the impacts of global change on biodiversity are hard to predict, difficult to control once they begin, and slow and expensive to reverse once they have occurred" (Leadley et al. 2010). Fortunately, EBM and EbA provide useful, practical strategies for dealing with these uncertainties.

Acknowledgements This chapter was reviewed in accordance with the policy of the Center for Environmental Measurement \& Modeling, U.S. Environmental Protection Agency, and approved for publication. However, the research presented was not performed or funded by EPA and was not subject to EPA's quality system requirements. Approval for publication does not signify that the contents necessarily reflect the view and policies of the Agency, nor does mention of trade names or commercial products constitute endorsement or recommendation for use. The authors express sincere thanks to the Mekong River Commission (MRC) Climate Change and Adaptation Initiative (CCAI) for funding this research and providing GIS and climate data. Aekkapol Aekakkararungroj (ADPC SERVIR-Mekong) is credited with providing Figure 1. The US State Department Embassy Science Fellows Program is acknowledged for sponsoring John M. Johnston to collaborate with the MRC on this study.

Disclaimer This chapter has been subjected to Agency review and has been approved for publication. The views expressed in this paper are those of the author(s) and do not necessarily reflect the views or policies of the U.S. Environmental Protection Agency.

\section{References}

Bagstad, K. J., Semmens, D. J., Waage, S., \& Winthrop, R. (2013a). A comparative assessment of decision-support tools for ecosystem services quantification and valuation. Ecosystem Services, 5(0), 27-39. https://doi.org/10.1016/j.ecoser.2013.07.004.

Bagstad, K. J., Semmens, D. J., \& Winthrop, R. (2013b). Comparing approaches to spatially explicit ecosystem service modeling: A case study from the San Pedro River, Arizona. Ecosystem Services, 5(0), 40-50. https://doi.org/10.1016/j.ecoser.2013.07.007.

Bai, Y., Zhuang, C., Ouyang, Z., Zheng, H., \& Jiang, B. (2011). Spatial characteristics between biodiversity and ecosystem services in a human-dominated watershed. Ecological Complexity, 8 (2), 177-183. https://doi.org/10.1016/j.ecocom.2011.01.007.

CEPF. (2011). Ecosystem profile: Indo-Burma biodiversity hotspot. Retrieved from https://www. cepf.net/sites/default/files/final.indoburma_indochina.ep_.pdf 
Chiang, L.-C., Lin, Y.-P., Huang, T., Schmeller, D. S., Verburg, P. H., Liu, Y.-L., \& Ding, T.-S. (2014). Simulation of ecosystem service responses to multiple disturbances from an earthquake and several typhoons. Landscape and Urban Planning, 122(0), 41-55. https://doi.org/10.1016/ j.landurbplan.2013.10.007.

Daily, G. C., Polasky, S., Goldstein, J., Kareiva, P. M., Mooney, H. A., Pejchar, L., et al. (2009). Ecosystem services in decision making: Time to deliver. Frontiers in Ecology and the Environment, 7(1), 21-28. https://doi.org/10.1890/080025.

Delphin, S., Escobedo, F. J., Abd-Elrahman, A., \& Cropper, W., Jr. (2013). Mapping potential carbon and timber losses from hurricanes using a decision tree and ecosystem services driver model. Journal of Environmental Management, 129(0), 599-607. https://doi.org/10.1016/j. jenvman.2013.08.029.

Feng, M., Liu, S., Euliss, N. H., Jr., Young, C., \& Mushet, D. M. (2011). Prototyping an online wetland ecosystem services model using open model sharing standards. Environmental Modelling \& Software, 26(4), 458-468. https://doi.org/10.1016/j.envsoft.2010.10.008.

Fu, B., Wang, Y. K., Xu, P., Yan, K., \& Li, M. (2014). Value of ecosystem hydropower service and its impact on the payment for ecosystem services. Science of The Total Environment, 472(0), 338-346. https://doi.org/10.1016/j.scitotenv.2013.11.015.

Harmáčková, Z. V., \& Vačkáŕ, D. (2015). Modelling regulating ecosystem services trade-offs across landscape scenarios in Třeboňsko Wetlands Biosphere Reserve, Czech Republic. Ecological Modelling, 295(0), 207-215. https://doi.org/10.1016/j.ecolmodel.2014.10.003.

Hoyer, R., \& Chang, H. (2014). Assessment of freshwater ecosystem services in the Tualatin and Yamhill basins under climate change and urbanization. Applied Geography, 53(0), 402-416. https://doi.org/10.1016/j.apgeog.2014.06.023.

ISPONRE. (2013). Operational framework for ecosystem-based adaptation to climate change for Vietnam: A policy supporting document. Retrieved from Hanoi, Viet Nam: http://awsassets. panda.org/downloads/wwf_vietnam_eba_operational_framework_2013.pdf.

IUCN. (2013). Ecological survey of the Mekong River between Louangphabang and Vientiane Cities, Lao PDR, 2011-2012. Retrieved from Vientiane, Lao PDR: https://cmsdata.iucn.org/ downloads/ecologicalsurveymekong_iucn_cepf.pdf.

Jackson, B., Pagella, T., Sinclair, F., Orellana, B., Henshaw, A., Reynolds, B., et al. (2013). Polyscape: A GIS mapping framework providing efficient and spatially explicit landscapescale valuation of multiple ecosystem services. Landscape and Urban Planning, 112(0), 74-88. https://doi.org/10.1016/j.landurbplan.2012.12.014.

Lassiter, R. R., Box, E. O., Wiegert, R. G., Johnston, J. M., Bergengren, J., \& Suárez, L. A. (2000). Vulnerability of ecosystems of the mid-Atlantic region, USA, to climate change. Environmental Toxicology and Chemistry, 19(4), 1153-1160. https://doi.org/10.1002/etc.5620190448.

Leadley, P., Pereira, H. M., Alkemade, R., Fernandez-Manjarrés, J. F., Proença, V., Scharlemann, J. P. W., \& Walpole, M. J. (2010). Biodiversity scenarios: Projections of 21 st century change in biodiversity and associated ecosystem services. Retrieved from Montreal, Canada: https://www. cbd.int/doc/publications/cbd-ts-50-en.pdf.

Leh, M. D. K., Matlock, M. D., Cummings, E. C., \& Nalley, L. L. (2013). Quantifying and mapping multiple ecosystem services change in West Africa. Agriculture, Ecosystems \& Environment, 165(0), 6-18. https://doi.org/10.1016/j.agee.2012.12.001.

Linke, P. (2014). On the development of strategies for water and energy management in the context of the water-energy-food nexus. In J. D. S. Mario R. Eden \& P. T. Gavin (Eds.), Computer aided chemical engineering (34, pp. 196-201). Amsterdam: Elsevier.

Marquès, M., Bangash, R. F., Kumar, V., Sharp, R., \& Schuhmacher, M. (2013). The impact of climate change on water provision under a low flow regime: A case study of the ecosystems services in the Francoli river basin. Journal of Hazardous Materials, 263(Part 1(0)), 224-232. https://doi.org/10.1016/j.jhazmat.2013.07.049.

MEA. (2005). Ecosystems and human health: Some findings from the Millenium ecosystem assessment. In Ecosystems and human well-being: Health synthesis. Geneva, Switzerland: World Health Organization. 
Metzger, M. J., Brus, D. J., Bunce, R. G. H., Carey, P. D., Gonçalves, J., Honrado, J. P., et al. (2013a). Environmental stratifications as the basis for national, European and global ecological monitoring. Ecological Indicators, 33, 26-35. https://doi.org/10.1016/j.ecolind.2012.11.009.

Metzger, M. J., Bunce, R. G. H., Jongman, R. H. G., Sayre, R., Trabucco, A., \& Zomer, R. (2013b). A high-resolution bioclimate map of the world: A unifying framework for global biodiversity research and monitoring. Global Ecology and Biogeography, 22(5), 630-638. https://doi.org/ 10.1111/geb.12022.

MONRE. (2013). Strengthening community and ecosystem resilience against climate change impacts: Lao PDR case study from field testing an operational framework for ecosystembased adaptation. Retrieved from Vientiane, Lao PDR: http://www.monre.gov.la/home/.

Monzón, J., Moyer-Horner, L., \& Palamar, M. B. (2011). Climate change and species range dynamics in protected areas. Bioscience, 61(10), 752-761. https://doi.org/10.1525/bio.2011. 61.10.5.

MRC. (2010). State of the Basin report 2010. Retrieved from Vientiane, Lao PDR: http://www. mrcmekong.org/assets/Publications/basin-reports/MRC-SOB-report-2010full-report.pdf.

MRC. (2011a). Assessment of basin-wide development scenarios: Main report. Vientiane, Laos: Mekong River Commission. http://www.mrcmekong.org/assets/Publications/basin-reports/ BDP-Assessment-of-Basin-wide-Dev-Scenarios-2011.pdf.

MRC. (2011b). Climate change adaptation initiative: 2011-2015 programme document. Retrieved from Vientiane, Lao PDR: http://www.mrcmekong.org/assets/CCAI-2011-2015documentFinal.pdf.

MRC. (2011c). Planning atlas of the lower Mekong River basin. Retrieved from http://www. mrcmekong.org/assets/Publications/basin-reports/BDP-Atlas-Final-2011.pdf

Munang, R., Thiaw, I., Alverson, K., Mumba, M., Liu, J., \& Rivington, M. (2013). Climate change and ecosystem-based adaptation: A new pragmatic approach to buffering climate change impacts. Current Opinion in Environmental Sustainability, 5(1), 67-71. https://doi.org/10. 1016/j.cosust.2012.12.001.

Ranganathan, J., Raudsepp-Hearne, C., Lucas, N., Irwin, F., Zurek, M., Bennett, K., et al. (2008). Ecosystem services: A guide for decision makers. Retrieved from http://pdf.wri.org/ecosystem services_guide_for_decisionmakers.pdf

Rasul, G. (2014). Food, water, and energy security in South Asia: A nexus perspective from the Hindu Kush Himalayan region. Environmental Science \& Policy, 39(0), 35-48. https://doi.org/ 10.1016/j.envsci.2014.01.010.

Ringold, P. L., Nahlik, A. M., Boyd, J., \& Bernard, D. (2010). Report from the workshop on indicators of final ecosystem goods and services for wetlands and estuaries. Retrieved from http://www.epa.gov/nheerl/arm/streameco/

Rosenthal, A., Arkema, K., Verutes, G., Bood, N., Cantor, D., Fish, M., et al. (2013). Identification and valuation of adaptation options in coastal-marine ecosystems: Test case from Placencia, Belize. Retrieved from Stanford University: https://www.mpaaction.org/sites/default/files/ Rosenthal\%20et\%20al_2013_Identification\%20and\%20Valuation\%20of\%20Adaptation\% 200ptions\%20in\%20Coastal-Marine\%20Ecosystems.pdf.

Sánchez-Canales, M., López Benito, A., Passuello, A., Terrado, M., Ziv, G., Acuña, V., et al. (2012). Sensitivity analysis of ecosystem service valuation in a Mediterranean watershed. Science of The Total Environment, 440(0), 140-153. https://doi.org/10.1016/j.scitotenv.2012. 07.071.

Sierra-Correa, P. C., \& Cantera Kintz, J. R. (2015). Ecosystem-based adaptation for improving coastal planning for sea-level rise: A systematic review for mangrove coasts. Marine Policy, 51 (0), 385-393. https://doi.org/10.1016/j.marpol.2014.09.013.

Singer, U. (2013). Livelihoods and resource management survey on the Mekong between LouangPhabang and Vientiane cities, Lao PDR. Retrieved from Vientiane, Lao PDR: https:// portals.iucn.org/library/sites/library/files/documents/2013-054.pdf.

$\mathrm{Su}$, C., \& Fu, B. (2013). Evolution of ecosystem services in the Chinese Loess Plateau under climatic and land use changes. Global and Planetary Change, 101(0), 119-128. https://doi.org/ 10.1016/j.gloplacha.2012.12.014. 
Trisurat, Y., Aekakkararungroj, A., Ma, H.-o., \& Johnston, J. M. (2018). Basin-wide impacts of climate change on ecosystem services in the Lower Mekong Basin. Ecological Research, 33(1), 73-86. https://doi.org/10.1007/s11284-017-1510-z.

Trisurat, Y., Shirakawa, H., \& Johnston, J. M. (2019). Land-use/land-cover change from socioeconomic drivers and their impact on biodiversity in Nan Province, Thailand. Sustainability, 11 (3), 649.

UNEP-WCMC. (2019). The world database on protected areas (WDPA). Retrieved from www. protectedplanet.net.

USGCRP. (2018). Impacts, risks, and adaptation in the United States: Fourth national climate assessment, Volume II. Retrieved from Washington, DC, USA: https://nca2018.globalchange. gov/.

Vigerstol, K. L., \& Aukema, J. E. (2011). A comparison of tools for modeling freshwater ecosystem services. Journal of Environmental Management, 92(10), 2403-2409. https://doi.org/10.1016/j. jenvman.2011.06.040.

Vignola, R., McDaniels, T. L., \& Scholz, R. W. (2013). Governance structures for ecosystem-based adaptation: Using policy-network analysis to identify key organizations for bridging information across scales and policy areas. Environmental Science \& Policy, 31(0), 71-84. https://doi. org/10.1016/j.envsci.2013.03.004.

Wamsler, C., Luederitz, C., \& Brink, E. (2014). Local levers for change: Mainstreaming ecosystembased adaptation into municipal planning to foster sustainability transitions. Global Environmental Change, 29(0), 189-201. https://doi.org/10.1016/j.gloenvcha.2014.09.008.

WWF. (2013). Ecosystems in the Greater Mekong: Past trends, current status, possible futures. Retrieved from wwf.panda.org/greatermekong.

Yokoyama, S., Tanaka, K., \& Phalakhone, K. (2006). Forest policy and Swidden agriculture in Laos. Paper presented at the NIE-SEAGA: Sustainability and Southeast Asia, Singapore.

Zhang, M.-G., Zhou, Z.-K., Chen, W.-Y., Cannon, C. H., Raes, N., \& Slik, J. W. F. (2014). Major declines of woody plant species ranges under climate change in Yunnan, China. Diversity and Distributions, 20(4), 405-415. https://doi.org/10.1111/ddi.12165.

Zomer, R. J., Trabucco, A., Metzger, M. J., Wang, M., Oli, K. P., \& Xu, J. (2014). Projected climate change impacts on spatial distribution of bioclimatic zones and ecoregions within the Kailash Sacred Landscape of China, India, Nepal. Climatic Change, 125(3), 445-460. https://doi.org/ 10.1007/s10584-014-1176-2.

Zomer, R. J., Xu, J., Wang, M., Trabucco, A., \& Li, Z. (2015). Projected impact of climate change on the effectiveness of the existing protected area network for biodiversity conservation within Yunnan Province, China. Biological Conservation, 184, 335-345. https://doi.org/10.1016/j. biocon.2015.01.031.

Open Access This chapter is licensed under the terms of the Creative Commons Attribution 4.0 International License (http://creativecommons.org/licenses/by/4.0/), which permits use, sharing, adaptation, distribution and reproduction in any medium or format, as long as you give appropriate credit to the original author(s) and the source, provide a link to the Creative Commons licence and indicate if changes were made.

The images or other third party material in this chapter are included in the chapter's Creative Commons licence, unless indicated otherwise in a credit line to the material. If material is not included in the chapter's Creative Commons licence and your intended use is not permitted by statutory regulation or exceeds the permitted use, you will need to obtain permission directly from the copyright holder.

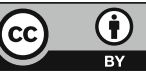

